\title{
Effects of human activities on long-term trends in sandy beach populations: the wedge clam Donax hanleyanus in Uruguay
}

\author{
Omar Defeo*, Anita de Alava \\ Instituto Nacional de Pesca, Casilla de Correo 1612, 11200 Montevideo, Uruguay
}

\begin{abstract}
A long-term analysis of the structure of a bivalve population consisting of the wedge clam Donax hanleyanus is described for an exposed temperate sandy beach of Uruguay. The potential effects of human harvesting on the sympatric bivalve Mesodesma mactroides (yellow clam) and of salinity were analyzed through time and space (longshore variation). Inter-and intra-annual fluctuations of the different population components (recruits, juveniles and adults) were detected. D. hanleyanus showed uneven periods of abundance, with the occurrence of peaks of different magnitude that appeared related to fluctuations in the fishing effort targeting on the yellow clam. D. hanleyanus showed a marked longshore variability in population structure and abundance along the $22 \mathrm{~km}$ of sandy beach sampled. Spatial variations in salinity and also in the amount of fishing effort exerted on M. mactroides seem to be key factors in explaining this variation. This study suggests that further research on sandy beach populations should include human activities as important factors affecting long-term trends.
\end{abstract}

KEY WORDS: Donax - Bivalves · Sandy beach · Long-term - Human impact · Uruguay

\section{INTRODUCTION}

Exposed marine beaches are physically stressed environments (sensu McLachlan 1983, 1988), and the invertebrate populations and communities living there are usually considered to be regulated mainly by physical factors. Thus, it is thought (McLachlan 1988, 1990) that the best way to understand population variability in these ecosystems is to document responses to abiotic factors. However, there is a conspicuous lack of information on the biotic factors (e.g. larval-adult interactions) as well as human-induced impacts (e.g. fishing activities) that are involved.

In contrast to the numerous studies conducted on populations and communities of exposed rocky shores (Paine 1984, Castilla \& Paine 1987, Castilla 1993, Navarrete et al. 1993), the macrofauna from exposed sandy

\footnotetext{
- Present address: Centro de Investigación y de Estudios Avanzados del IPN, AP 73 Cordemex, 97310 Mérida, Yucatán, México
}

beaches, which makes up the greatest proportion of most open shores (McLachlan 1990), has usually been the focus of short-term/instantaneous research, mainly related to community structure and zonation (Jaramillo 1978, Donn 1987, McLachlan 1990, Jaramillo \& McLachlan 1993). Very little is known about the long-term consequences of natural or human-induced disturbances on the structure and dynamics of sandy beach populations.

The wedge clam Donax hanleyanus (Philippi, 1845) (Bivalvia: Donacidae) occurs along the Atlantic coast of South America, from the state of Espiritu Santo (Brazil) (Narchi 1978) to Punta Mogotes, Buenos Aires Province (Argentina) (Penchaszadeh \& Olivier 1975). This intertidal filter-feeder has a maximum adult size of $35 \mathrm{~mm}$, and rarely lives for more than 3 yr (Penchaszadeh \& Olivier 1975, Defeo unpubl.). It is common on the reflective beaches, with coarse sediments and sharp slopes, of the coast of Uruguay (Pollovero 1984). However, it has also been categorized as an important species on the dissipative sandy beaches, with gentle 
slopes and fine grain size, of the coasts of Brazil (Gianuca 1983), Argentina (Olivier et al. 1971, Penchaszadeh \& Olivier 1975) and Uruguay (Defeo et al. 1992, de Alava 1993). In this setting, it is sympatric with the yellow clam Mesodesma mactroides (Bivalvia: Mesodesmatidae), in a community dominated by the latter.

Both species inhabit the $22 \mathrm{~km}$ of continuous sandy coast from Barra del Chuy to La Coronilla, Uruguay. In addition to natural biotic and abiotic factors, 2 forms of human-induced perturbation affect the nearshore, benthic environment in this area: (1) the freshwater discharge (Andreoni Canal) from a wide plain basin used for agriculture and cattle rearing, and subjected to agro-chemicals (Defeo 1993a); and (2) direct exploitation of Mesodesma mactroides and the physical disturbance associated with this harvest.

Mesodesma mactroides is commercially exploited with hand tools, notably shovels, mainly during austral summer months (December to March). The extraction of clams produces sediment disturbance which makes the substratum unsuitable for settlement, and there may be incidental damage to the unexploited size classes (i.e. less than $50 \mathrm{~mm}$ length) (Defeo 1993a). Although Donax hanleyanus is not commercially exploited, it occupies the same intertidal fringe as M. mactroides, and so also may be incidentally affected by harvesting activities.

In the present study we explore the following questions: (1) How does harvesting of Mesodesma mactroides affect temporal patterns of population variability and structure of the unexploited wedge clam D. hanleyanus? (2) Are the 2 forms of human-induced perturbations (freshwater discharge and harvesting activities) important in determining variations in abundance of the wedge clam population along the beach? To this end, we carried out long-term monitoring of both the population structure and abundance of $D$. hanleyanus and the fishing activities (catch and effort data) on $M$. mactroides. The $8 \mathrm{yr}$ study included a 32 mo experiment during which fishing was totally excluded (see Defeo 1993a and de Alava 1993 for details on the human exclusion experiment).

\section{METHODS}

Study area. The study area comprised $22 \mathrm{~km}$ of continuous sandy beach from Barra del Chuy $\left(33^{\circ} 40^{\prime} \mathrm{S}\right.$, $\left.53^{\circ} 20^{\prime} \mathrm{W}\right)$ to La Coronilla $\left(33^{\circ} 50^{\prime} \mathrm{S}, 53^{\circ} 27^{\prime} \mathrm{W}\right)$ on the Atlantic coast of Uruguay (Fig 1). This is a dissipative beach (sensu McLachlan 1990), with fine to very fine, well-sorted sands, a gentle slope, heavy wave action, a wide surf zone and large aeolian tide ranges. The physiognomy of this shoreline is determined mainly by the prevailing winds and wind-driven surf off the South Atlantic (Etchichury \& Remiro 1971, de Alava \& Defeo 1991).

The beach is delimited by a freshwater stream at each extreme: Chuy Stream in the north, and Andreoni Canal, $800 \mathrm{~m}$ south of La Coronilla (Fig. 1). Large variations in salinity values within the surf zone have been documented in both time and space (from 0.5 to $30 \mathrm{ppt}$ Defeo 1993a), and these are explained by the freshwater discharges at the 2 extremes of the beach (Defeo et al. 1986). The Andreoni Canal is also known to discharge pesticides and high concentrations of suspended solids (Méndez \& Anciaux 1991). In this study, variations in salinity are taken as an indicator for the presence of agricultural discharges, the effects of which are beyond the scope of this paper.

This stretch of beach has the highest richness of benthic macrofauna (mesh size $=0.5 \mathrm{~mm}$ ) in Uruguay (Defeo et al. 1992). It also has high, aperiodic values of primary production $\left(6 \times 10^{9} \mathrm{cell}^{-1}\right)$ throughout the year (Bayssé et al. 1989), and hence has been described as the most southerly of a chain of exposed sandy beaches (Defeo \& Scarabino 1990) which form semi-closed ecosystems (sensu McLachlan 1980).

Sampling procedures and data analysis. Samples of clams were collected monthly from March 1983

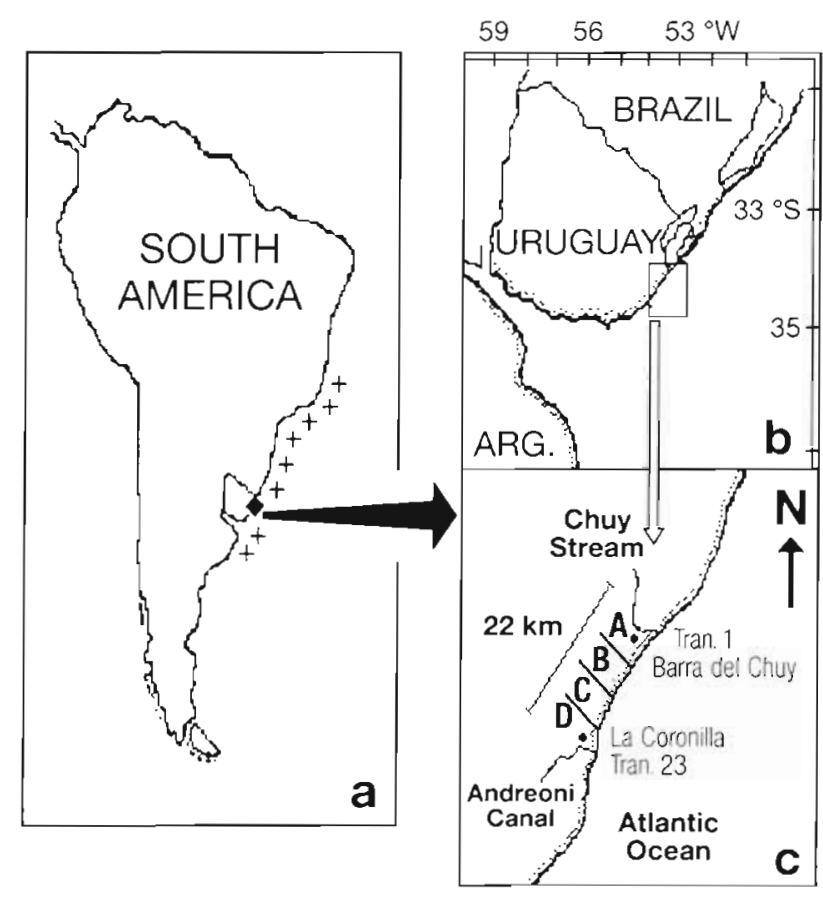

Fig. 1 (a) Geographic distribution (+) of the wedge clam Donax hanleyanus. (b) Study area on the eastern coast of Uruguay. (c) Location of the 4 fishing grounds along the $22 \mathrm{~km}$ of beach sampled between Chuy Stream and Andreoni Canal; Barra del Chuy and La Coronilla are also shown 
through March 1985, and seasonally (at least 4 times a year) from 1985 to 1990 , according to a systematic design developed to evaluate the stock of Mesodesma mactroides. Transects perpendicular to the shoreline were set up every kilometer from Barra del Chuy (transect 1) to La Coronilla (Transect 22), with sampling stations on each transect beginning at the base of the dunes and continuing at $4 \mathrm{~m}$ intervals to the seaward limit of the clam bed, until at least 2 consecutive stations yielded no wedge clams. More than 200 samples were taken during each sample period. At each station, a sheet metal cylinder, $28.2 \mathrm{~cm}$ in diameter and $40 \mathrm{~cm}$ deep, was used to remove the sediment. Each sample was sieved through a $0.5 \mathrm{~mm}$ mesh, and the organisms retained were collected and later measured in the laboratory with a vernier caliper along the greatest valve length. Measurements were recorded to the nearest $0.5 \mathrm{~mm}$, and covered the full range of Donax hanleyanus sizes: 1 to $33 \mathrm{~mm}$. From February 1988 to March 1990, intensive monthly sampling was conducted in the middle of the study area (Transect 10). Here, 8 additional transects were set up perpendicular to the shoreline and spaced $8 \mathrm{~m}$ apart. Stations were established and sampled in the manner described above. Also during this period, additional sampling was carried out monthly near the Andreoni Canal (Transect 23). During this intensive sampling, more than 50 samples were analyzed each month, in addition to those collected from the entire study area.

Because of wide differences in spatial distribution of fishing effort and catches of Mesodesma mactroides along the beach (Defeo 1993a), the study area was divided into 4 fishing grounds for the purpose of grouping data from the fishery (see Defeo et al. 1991 for details), with boundaries set at right angles to the coastline: A, Transects 1 through 5; B, Transects 6 through $10 ; C$, Transects 11 through 15; and $D$, Transects 16 through 22 (Fig. 1c). No fishing activities were ever observed between Transect 22 (La Coronilla) and 23 (Andreoni Canal).

Wedge clams were categorized into 3 size classes: recruits, 1 to $5 \mathrm{~mm}$; juveniles, 5.5 to $15 \mathrm{~mm}$; and adults, $>15 \mathrm{~mm}$ (de Alava 1993). The mean size at first maturity (15 mm; Penchaszadeh \& Olivier 1975) was used to identify the adult component. Average mean density of each size class was calculated for every sampling period, by transect, by fishing ground, and also as an overall average for each sample period.

The period of wedge clam recruitment was found to occur between February 1 and May 31 (de Alava 1993). In both 1988 and 1989 the main peak in recruitment occurred between 2 seasonal samplings (de Alava 1993), so the best data for interpreting the seasonal peak of recruitment came from the intensive sampling at Transect 10 . Thus, for these 2 years data on recruitment by fishing ground was not obtained, and only an estimate for the entire beach was available.

Daily records of fishing effort (man-hours $d^{-1}$ and number of trips) and catches per fishermen were maintained by fishing ground from 1984 to 1987 and from 1990 onwards. Monthly catch data records for Mesodesma mactroides were available from 1983. Both fishing effort and annual harvest increased steadily from $62 \mathrm{t}$ in 1981 to $219 \mathrm{t}$ in 1985 (Defeo 1989). After 1985 there was a marked drop in catches and catch per unit effort; a human exclusion experiment was carried out along the entire beach between April 1987 and November 1989, at which time the resource was judged to have recovered (Defeo 1993b, Defeo et al. 1993).

Sea surface salinity was measured during each sampling period with a Beckman salinometer at oddnumbered transects, and also at Transect 22. During the period of intensive sampling, between February 1988 and March 1990, salinity was measured at Transects 10,22 and 23 .

\section{RESULTS}

\section{Temporal variations}

The average annual density of Donax hanleyanus population showed a clear increase over the 8 yr study period; the lowest value was registered in 1984 (19 ind. $\mathrm{m}^{-2}$ ) and the highest in 1990 (178 ind. $\mathrm{m}^{-2}$ ). Variation in density values was highest in 1987, the first year that the Mesodesma mactroides fishery was closed, and lowest the 3 previous years (1984 to 1986).

This increasing trend in average annual density was similar for each of the 3 size classes. However, both recruit and juvenile densities showed greater seasonal variation than adult densities (Fig. 2a, b). Recruits commonly showed a strong peak in density during the summer and autumn (February to May), notably in 1983, 1987 and 1990 , with the highest value of 322 ind. $\mathrm{m}^{-2}$ recorded in summer 1990 (Fig. 2a). The 4 yr period between 1983 and 1987 - before the closure of the fishery - was characterized by a long series of low values, never above 50 ind. $\mathrm{m}^{-2}$. The high summer peak in recruits in 1987 occurred just when the Mesodesma mactroides fishery was closed, and the even higher peak in summer 1990 occurred just as the fishery was reopened in December 1989, after 32 mo of having been closed.

Average seasonal densities of juveniles (Fig. 2b) revealed a similar pattern, showing peaks in the summers of 1983, 1987 and 1990. There was also a strong winter peak in 1988 (125 ind. $\mathrm{m}^{-2}$ ), just $1.5 \mathrm{yr}$ after the Mesodesma mactroides fishery had been closed in April 1987. The period before the closure of the fishery showed low and constant average seasonal 

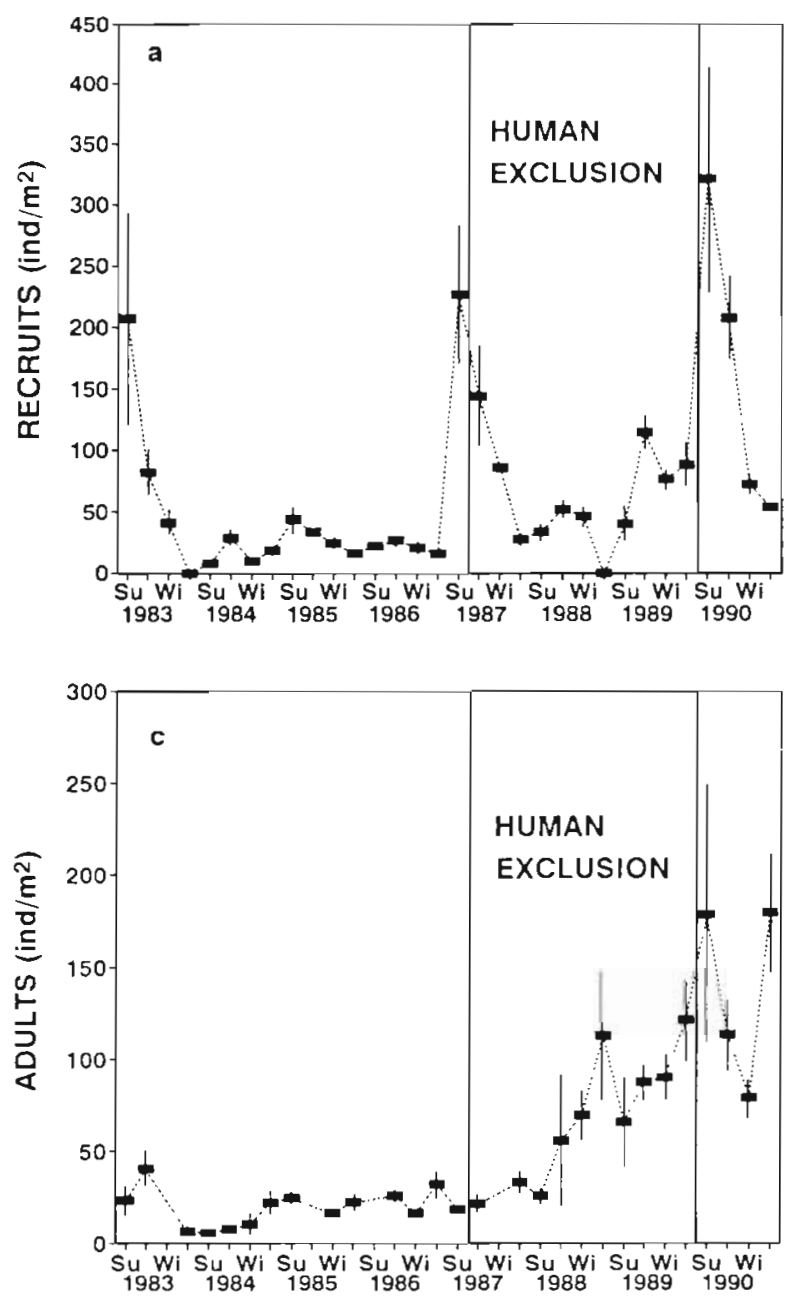

density values, all below 50 ind. $\mathrm{m}^{-2}$. After winter 1989, density stayed above 100 ind. $\mathrm{m}^{-2}$

Seasonal densities of adults (Fig. 2c) were consistently below 50 ind. $\mathrm{m}^{-2}$, from the beginning of the study until spring 1988, when they peaked at 112 ind. $\mathrm{m}^{-2}$. From that point on, density values were above 75, and frequently greater than 100 ind. $\mathrm{m}^{-2}$. They peaked again in spring and summer 1990 (179 ind. $\mathrm{m}^{-2}$ ). Hence, a year after the closure of the Mesodesma mactroides fishery, the adult wedge clam population began to rise steadily from its previous low base.

\section{Longshore variations}

The wedge clam population

To dampen the effect of temporal fluctuations in stock and recruitment, average annual densities per transect were normalized; this procedure frees the data from the effect of scale (Austin \& Greig-Smith

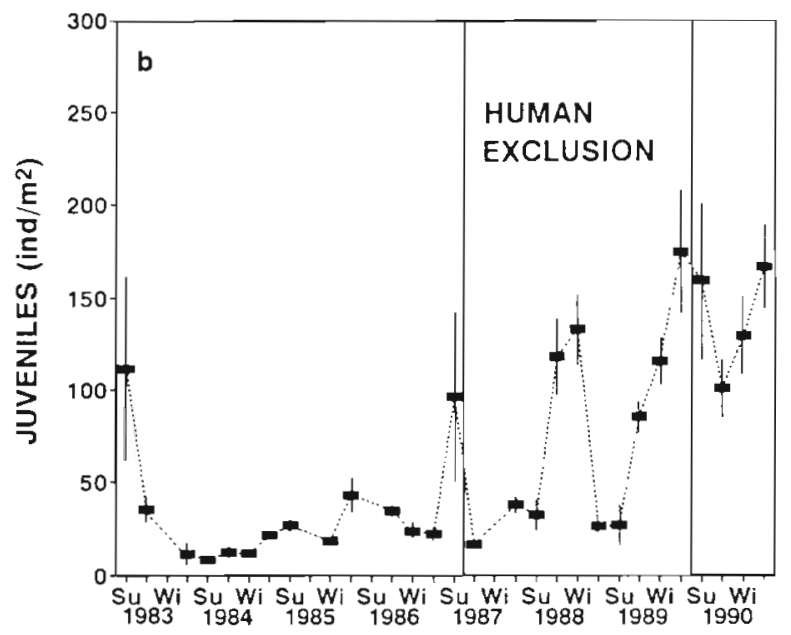

Fig. 2. Donax hanleyanus. Seasonal fluctuations in density (mean $\pm \mathrm{SE}$ ) in the study zone. (a) Recruits; (b) juveniles; and (c) adults. The period during which the Mesodesma mactroides fishery was closed (April 1987 to November 1989 ) is also indicated. Su: summer; Wi: winter

1968, Green 1979). The transformed data showed that the abundance of recruits was lowest in Transects 12 through 22 (grounds C and D), declining sharply in the transects closest to the Andreoni Canal (Fig. 3a). A decrease in abundance at Transect 1 (northern extreme) was also evident. Adults showed a steady decrease in abundance from Transect 17 to 22 , but the transects north of 17 showed no clear spatial trend, except a marked drop in abundance at Transect 1 (Fig. 3b). As the data (whether raw or variously transformed) did not meet the assumption of homoscedasticity ( $\mathrm{p} \ll 0.01$, Bartlett and Cochran tests), nonparametric tests were employed to evaluate differences among transects. Normalized data of recruitment during recruitment time and mean annual densities of adults (mean per transect; all 8 years pooled) differed significantly among transects, according to the Friedman nonparametric analysis of variance $\left(\chi_{r^{2} 8.21}=\right.$ 40.20; $p<0.01$ for recruits and $\chi_{r^{2} 8.21}=34.19, p<0.03$ for adults). The gradient mentioned above, especially in transects belonging to ground D (i.e. Transects 16 to 22), accounted for these differences (Fig, 3a, b) 

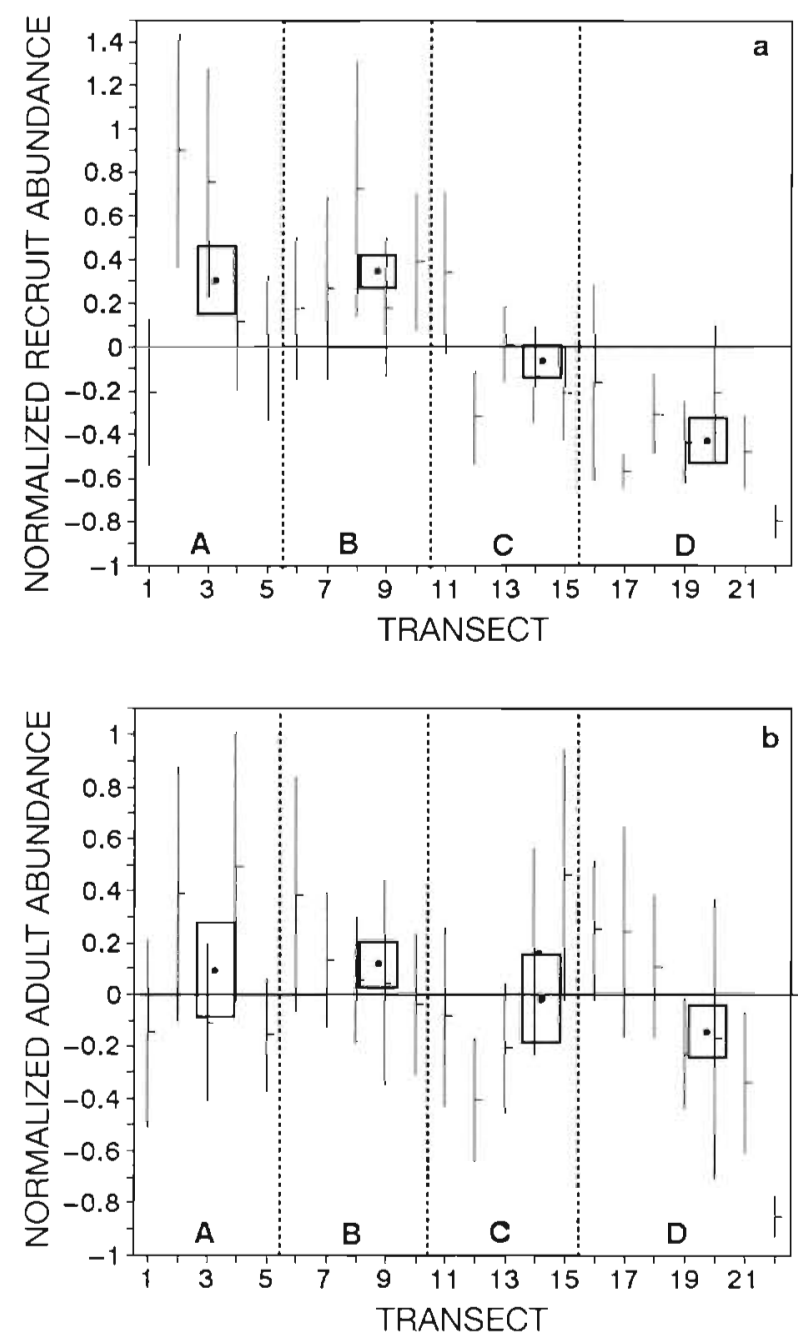

Fig. 3. Donax hanleyanus. Longshore variability. (a) Recruit and (b) adult abundance for the 22 transects for the period 1983 to 1990 . Box plots represent the mean normalized values \pm SE per fishing ground

A significant positive correlation $(\mathrm{r}=0.57 ; \mathrm{p} \ll 0.01)$ between density of juveniles plus adults $(A)$ and density of recruits $(R)$ in transect $i$ for year $y$ was observed during the recruitment period (February to May). A model of the form:

$$
R_{x y}=a A_{y y}^{b}
$$

$(a=2.40 ; b=0.637)$ best described the relation between the longshore spatial variation of recruits and adults for the 22 transects in the 8 years analyzed (Fig. 4).

\section{Salinity}

Fig. 5 shows the spatial variation in salinity values during the wedge clam recruitment period (February to Mayl for 5 of the 8 years of study. Mean values were

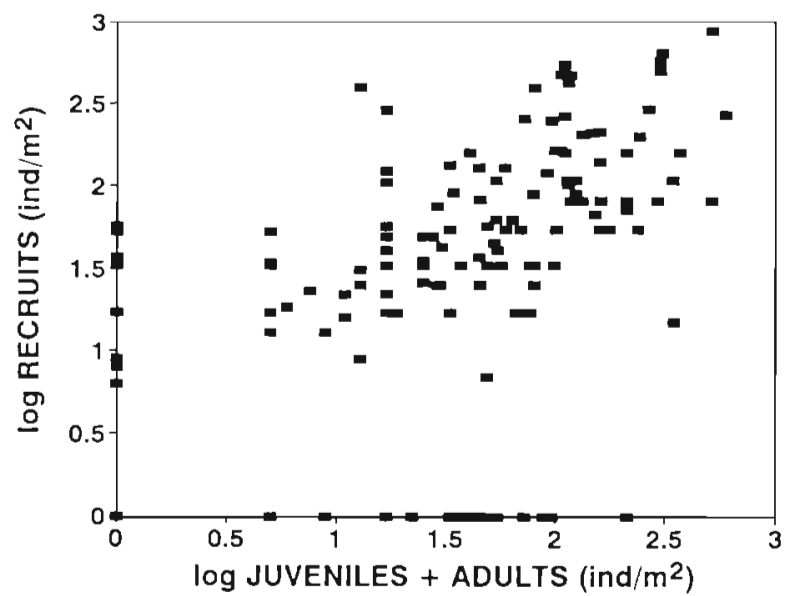

Fig. 4. Donax hanleyanus. Scatter diagram of recruit density plotted against juvenile + adult density (mean values) per transect during each recruitment period, between 1983 and 1990

generally about $27 \mathrm{ppt}_{i}$ however, in 1985 they rose to $31 \mathrm{ppt}$, and in 1986 they dropped to $19 \mathrm{ppt}$. In all 5 years there was a consistent pattern of lower values at the south end of the study area (Transect 22). In 1984 and 1988 there were also markedly lower values in salinity at Transect 1 ; however, during the other 3 years there was no such pattern (Fig. 5). The data obtained in 1988-1989 from the intensive sampling, although limited to Transects 10 ( $27 \pm 1 \mathrm{ppt}), 22(24 \pm 2 \mathrm{ppt})$ and 23 $(5 \pm 3 \mathrm{ppt})$, were consistent with these general patterns.

\section{The Mesodesma mactroides fishery and its effect on the Donax hanleyanus population}

Heterogeneous allocation of fishing effort seems to be a consistent feature in the exploitation of Meso-

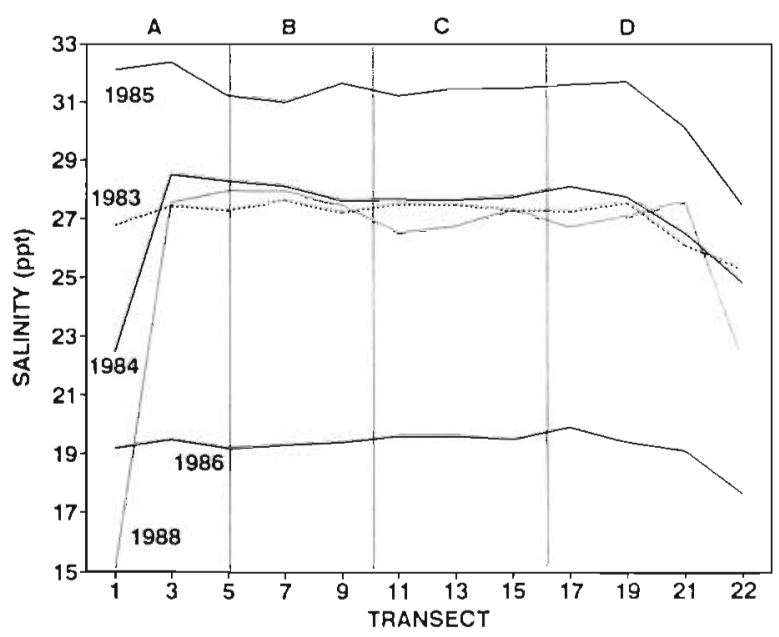

Fig. 5. Spatial variability in mean salinity values at the time of Donax hanleyanus recruitment for 5 of the 8 years analyzed 
desma mactroides in the study site, as has been shown in previous studies (Defeo et al. 1986, 1991). The largest catches were recorded in the central fishing grounds B and C (Fig. 6).

Average density of wedge clam recruits per fishing zone during the recruitment period showed a significant inverse relation to fishing effort (in number of trips) exerted on Mesodesma mactroides in fishing grounds $A, B$ and $C$, but not in D (Fig. 7). An analysis of covariance was performed with recruitment density as the predicted variable, fishing effort as the covariate, and fishing grounds as factors. The hypothesis of equal slopes was rejected $\left(F_{3,15}=4.23 ; p<0.024\right)$, which could denote a dissimilar capacity for recruitment success and recolonization (Fig. 7: grounds A to C). From the linear regression analyses, the greatest recruitment density ( 311 recruits $\mathrm{m}^{-2}$ ) in the absence of fishing effort should be expected in ground $A$, and the lowest in ground $\mathrm{D}$.

This phenomenon was also reflected in the strong inverse relation between the mean density of recruits at recruitment time averaged over the entire beach and the catch of yellow clams during the same period for the 8 years studied (Fig. 8a). A significant $(r=-0.82$;

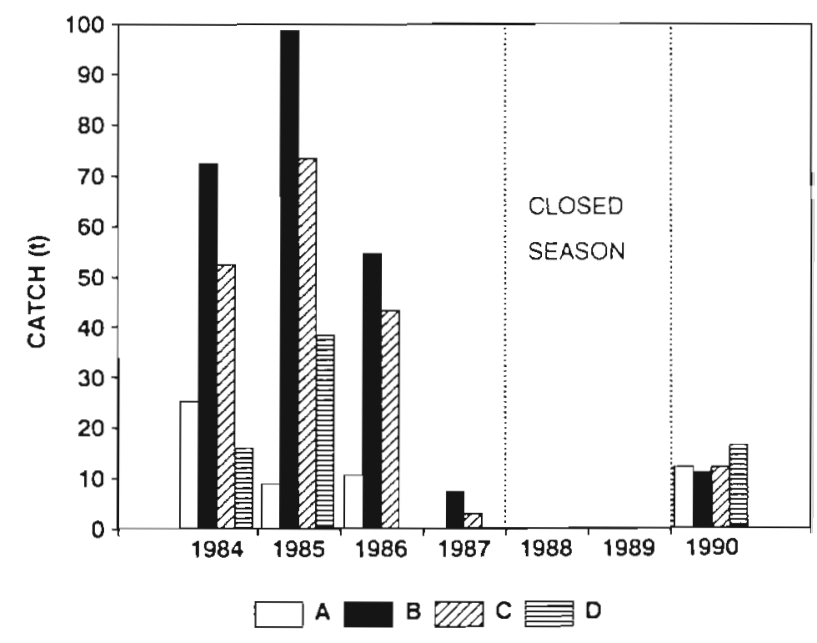

Fig. 6. Time series of yellow clam Mesodesma mactroides catches per fishing ground 1984 to 1990 . Between autumn (April) 1987 and spring (November) 1989 the fishery was closed

$\mathrm{p}<0.013$ ) monotonically decreasing exponential function of the form

$$
R_{y}=173 \mathrm{e}^{-0.021 C_{y}}
$$
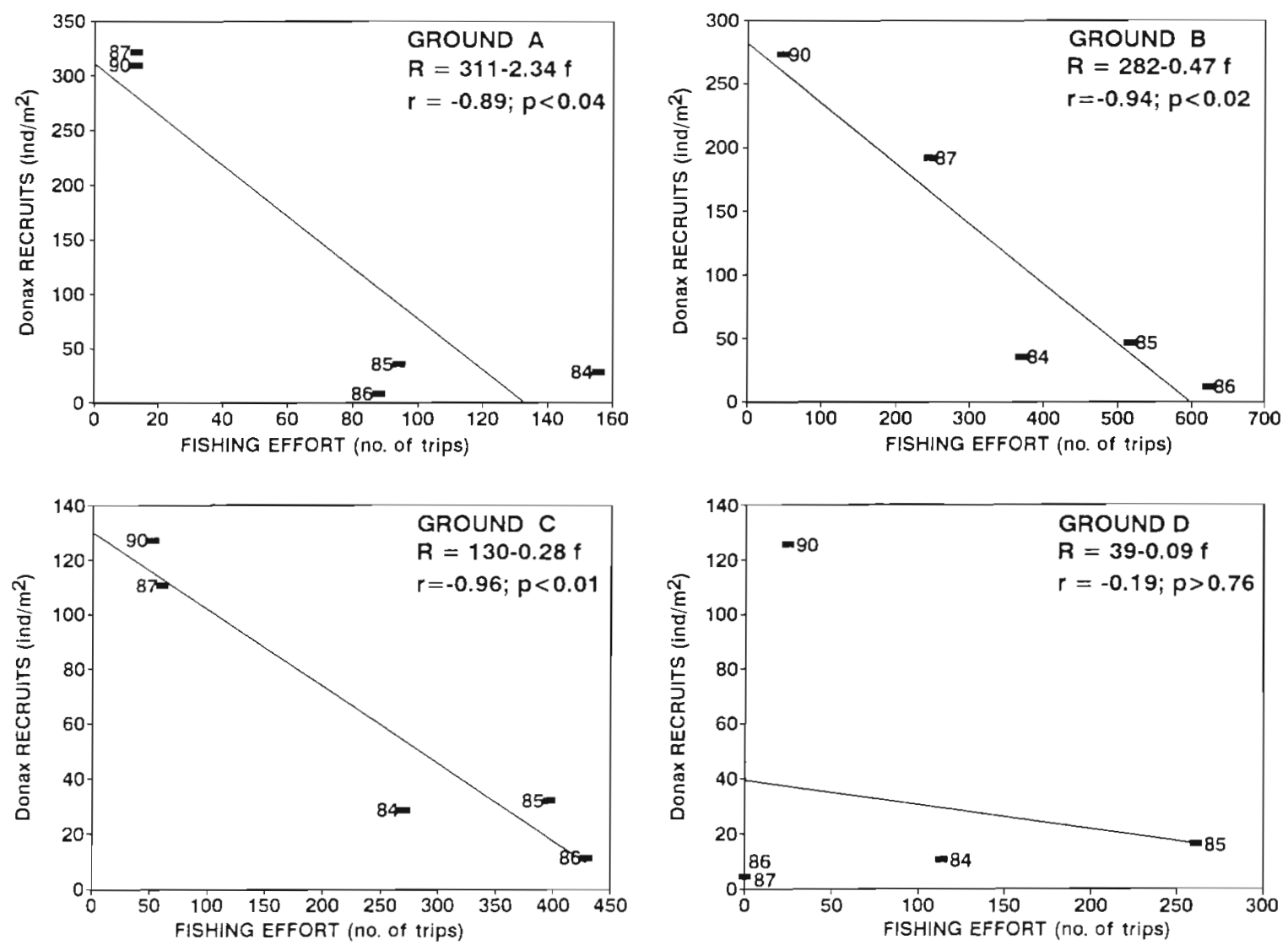

Fig. 7. Bivariate correlation per fishing ground between Donax hanleyanus recruitment density and the corresponding fishing effort exerted on Mesodesma mactroides. Years without fishing activity were not considered (see 'Methods') 
was fitted, where $R_{y}$ is the recruitment density during recruitment time of year $y$ and $C_{y}$ is the recorded Mesodesma mactroides catch. The above relationship was also observed when considering the annual mean density corresponding to the juvenile + adult population components pooled together and the total annual catch $(r=-0.75 ; p<0.03 ;$ Fig. 8b). The function fitted was:

$$
A_{y}=107 \mathrm{e}^{-0.007 C_{y}}
$$

where $A_{y}$ is the density of juveniles + adults averaged over all transects during year $y$ and $C_{y}$ is the corresponding catch.

\section{DISCUSSION}

In a recent overview, Castilla (1993) called attention to the scarcity of studies on the effects of humans on
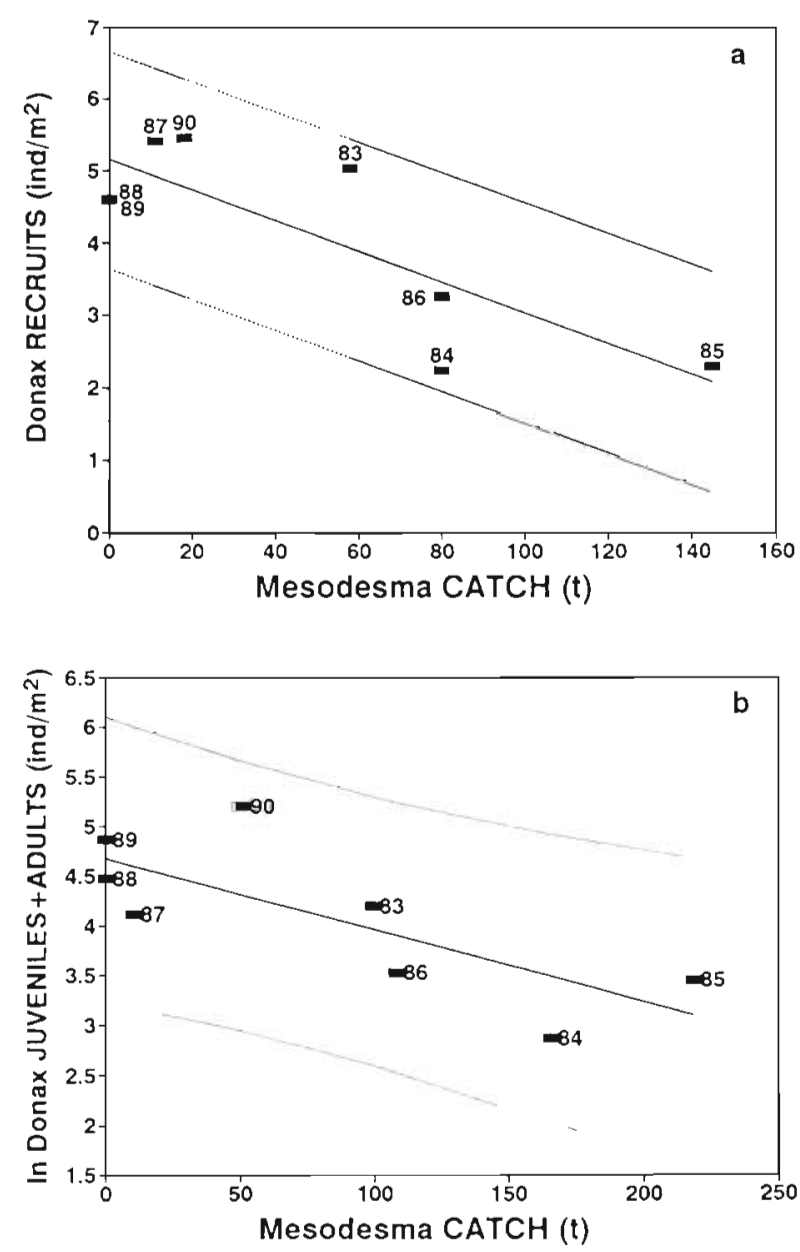

Fig. 8. Bivariate correlation ( $\pm 95 \%$ confidence intervals) of (a) recruits and (b) juveniles + adults of Donax hanleyanus with Mesodesma mactroides catches, estimated (a) during recruitment time and (b) on an annual basis. Data from the intensive sampling survey was employed to estimate the mean recruitment density for 1988-1989 (see 'Methods') coastal invertebrates, even though humans are likely to constitute the key factor ('capstone') which disturbs or alters populations, communities and/or ecosystems, generating cascading effects which affect their structure and functioning (Estes \& Palmisano 1974, Moreno et al. 1984, Castilla \& Durán 1985, Durán \& Castilla 1989). The long-term study of the wedge clam population described here, constitutes one of the first examples in the literature on sandy beaches that illustrates the effects of human activities on intertidal populations.

Donax hanleyanus showed temporal variations in density, with peaks occurring when fishing effort exerted on the yellow clam Mesodesma mactroides was lowest. The highest densities of $D$. hanleyanus occurred consistently throughout and immediately after the human exclusion experiment; the peaks during the period of exploitation $(1983,1987)$ coincided with the lowest $M$. mactroides catches and fishing effort. Moreover, when the area was closed to fishing (from April 1987 to December 1989), recruitment promoted a rapid increase in population growth to a level above that observed during exploitation.

Two facts derived from the long-term analysis of Donax hanleyanus abundance and the intensity of fishing activity on Mesodesma mactroides would suggest a potential ecological interdependence between the 2 suspension-feeding bivalves: (1) density of the wedge clam (recruits as well as juveniles plus adults) was inversely correlated with the size of yellow clam catches; (2) maximum abundances of both recruits and adults of $M$. mactroides during the period of exploitation occurred between 1984 and 1985 (Defeo 1993b), coinciding with the period of lowest wedge clam population abundances (see Fig. 2) and the highest catches of yellow clam (see Fig. 6). The divergence in the relation of the 2 clams to fishing suggests a dissimilar response to human disturbance, and hence a possible competitive dominance of $M$. mactroides in the colonization of the released space after harvesting. It must be emphasized that recruits and adults of $D$. hanleyanus and recruits and juveniles of $M$. mactroides occur at similar depths in the sediment (Defeo et al. 1986); thus an intense competitive interaction resulting from competition for space could be expected as a primary mechanism of population regulation (see also Peterson \& Andre 1980). Interspecific competition for space has been suggested to be one way $M$. mactroides and $D$. hanleyanus are regulated on Argentinian coasts (Penchaszadeh \& Olivier 1975). Intense interactions between age classes of the sympatric surf clams Mesodesma donacium and Donax peruvianus from the Pacific sandy beaches of South America, have also been proposed (Arntz et al. 1987).

In the present study, Donax hanleyanus showed a marked longshore variability in population structure 
along the $22 \mathrm{~km}$ of sandy beach sampled. The lowest abundances of recruits were observed in Transects 1 , 22 and 23, and the highest in ground $A$ (i.e. Transects $2,3)$. This fact could be explained by the lower salinities close to the Andreoni Canal, and to a lesser extent near the Chuy Stream (Transect 1). These results agree with those found by Defeo (1993a), who showed that changes in physico-chemical variables (e.g. nutrients, seston) of the coastal water near the Andreoni Canal were responsible for the striking decline in the abundance and diversity of the nearshore benthic and phytoplanktonic communities of this beach. Over the same study area, the abundance of marine phytoplankton decreased towards the Andreoni Canal, evidently as a consequence of decreasing nearshore salinity (Bayssé et al. 1989, Defeo 1993a). Bayssé et al. (1989) documented this gradient for marine diatoms such as Asterionella glacialis, which constitutes a basic food source for Mesodesma mactroides and probably for Donax hanleyanus as well (Gianuca 1983, Defeo \& Scarabino 1990). Thus, longshore variability in abiotic (salinity) and biotic (phytoplankton) factors may also be important in defining those areas with a greater probability of successful recruitment. Moreover, the large amount of sediment and sewage carried by the freshwater discharges from the Andreoni Canal, and the observed constant erosion of the site (Defeo 1993a), would suggest a constantly changing environment, and possibly a less suitable habitat for the wedge clam.

The apparent influence of salinity on the distribution of the wedge clam suggests a pattern different from those documented for Donax species throughout the world. Sastre (1984) concluded that food availability was the major factor affecting populations of Donax denticulatus, so that abundance and maximum size of individuals were greatest on beaches with the highest levels of particulate organic carbon. McLachlan \& Hanekom (1979) suggested that particulate matter from river mouths and phytoplankton blooms have a positive effect on populations of Donax serra on South African coasts. Similarly, Donn (1987) found that the population structure of $D$. serra appeared to be strongly skewed towards river mouths (see also Wade 1967, Ansell 1983). In this study, the spatial gradient in density was sharper for recruits than for adults, although the latter showed a marked reduction towards the Andreoni Canal. Thus, the longshore distribution of the $3 \mathrm{D}$. hanleyanus population classes (recruits, juveniles and adults) can be considered as habitat-dependent, with decreasing abundances occurring at marginal sites. Differential mortality due to differences in salinity and food availability could affect the distributional pattern. The occurrence of differential mortality resulting from gradients in habitat quality has been reported by Moüeza \& Chessel (1976) for
Donax trunculus and reviewed by Bachelet et al. (1992) for suspension-feeders.

The longshore distribution of Donax hanleyanus in Uruguay could also be explained by the spatial variability in the intensity of harvesting activities. Incidental effects (shell damage) of fishing pressure were observed for yellow clams below the size harvested (Defeo 1993a) and are certain to also affect the wedge clam. In addition, physical stress produced by sediment disturbance could make the substratum less suitable for settlement. The significant correlations between wedge clam abundance and fishing effort are a first step in identifying potential effects of harvesting and destruction of sediment structure affecting longterm patterns in sandy beach populations; however, such effects need to be tested through direct quantification of incidental damage and the effects of substrate perturbation (e.g. mortality of wedge clams immediately after fishing manipulation versus a small control area).

In summary, 2 different sources of human impact appeared to produce the distribution patterns of the wedge clam population observed in the field: (1) the fishing activity exerted on the sympatric bivalve Mesodesma mactroides, especially in grounds $\mathrm{A}$ to $\mathrm{C}$; (2) in ground D, in which fishing effort exerted on $M$. mactroides was the lowest and was a less reliable predictor of wedge clam recruitment abundance, the salinity variations caused by the Andreoni Canal. The relative importance of the harshness of the physical environment could outweigh the effect of human exploitation in this zone.

As in rocky intertidal species, for which the effects of intense fishing pressure have been well documented (Castilla \& Durán 1985, Moreno et al. 1986, Oliva \& Castilla 1986), the present study shows that humans could also play a critical role in determining the magnitude of fluctuations of sandy beach populations, not only for the target species subjected to exploitation but for other species in the community as well. Hence, research on sandy beach populations should include consideration of human activities as key factors in regulating long-term fluctuations.

Acknowledgements. The authors express their deepest gratitude to J. Frazier, S. Navarrete, T Scholz, B. Davies and 3 anonymous reviewers for critical reading of and valuable suggestions on the final manuscript. We thank M. L. Arín, A. Brazeiro, C. Layerle, A. Masello, G. Riestra and G. SosaDias for field and laboratory assistance.

\section{LITERATURE CITED}

Ansell AD (1983) The biology of the genus Donax. In: Mclachlan A, Erasmus T (eds) Sandy beaches as ecosystems. W Junk, The Hague, p 607-636 
Arntz WE, Brey T, Tarazona J, Robles A (1987) Changes in the structure of a shallow sandy-beach community in Peru during an El Niño event. In: Payne AIL, Gulland JA, Bink $\mathrm{KH}$ (eds) The Benguela and comparable ecosystems. S Afr $\mathrm{J}$ mar Sci 5:645-658

Austin MP, Greig-Smith P (1968) The application of quantitative methods to vegetation survey. II. Some methodological problems of data from rain forest. J Ecol 56:827-844

Bachelet G, Desprez M, Ducrotoy JP, Guillou J, Labourg PJ, Rybarczyk H, Sauriau PG. Elkaïm B, Glémarec M (1992) Rôle de la compétition intraspécifique dans la régulation du recrutement chez la coque, Cerastoderma edule (L.). Annls Inst océanogr, Paris 68:75-87

Bayssé C, Elgue JC, Burone F (1989) Variaciones en la distribución y relaciones interespecíficas del fitoplancton en una playa arenosa de la costa atlántica uruguaya. Fr Mar $5: 95-114$

Castilla JC (1993) Humans: capstone strong actors in the past and present coastal ecological play. In: McDonnell MJ, Pickett STA (eds) Humans as components of ecosystems. The ecology of subtle human effects and populated areas. Springer-Verlag, New York, p 158-162

Castilla JC, Durán R (1985) Human exclusion from the rocky intertidal zone of Central Chile: the effects on $C$. concholepas (Mollusca: Gastropoda: Muricidae). Oikos 45: 391-399

Castilla JC, Paine RT (1987) Predation and community organization on Eastern Pacific, temperate zone, rocky intertidal shores. Rev Chil Hist nat 60:131-151

de Alava A (1993) Interdependencias ecológicas entre dos bivalvos simpátricos en una playa arenosa de la costa atlántica uruguaya. MSc thesis, Centro de Investigación de Estudios Avanzados del Instituto Politécnico Nacional, Mérida

de Alava A, Defeo O (1991) Distributional pattern and population dynamics of Excirolana armata (Isopoda: Cirolanidae) in a Uruguayan sandy beach. Estuar coast Shelf Sci 33:433-444

Defeo O (1989) Development and management of artisanal fishery for yellow clam Mesodesma mactroides in Uruguay. Fishbyte $7: 21-25$

Defeo O (1993a) The effect of spatial scales in population dynamics and modelling of sedentary fisheries: the yellow clam Mesodesma mactroides of an Uruguayan exposed sandy beach. PhD thesis, Centro de Investigación de Estudios Avanzados del Instituto Politécnico Nacional, Mérida

Defeo O (1993b) Repopulation of coastal invertebrates through the management on natural areas: a successful example. Out Shell 3:11-13

Defeo O, de Alava A, Valdivieso V, Castilla JC (1993) Historical landings and management options for the genus Mesodesma in coasts of South America. Biol pesq (Chile) $22: 41-54$

Defeo O, Jaramillo E, Lyonnet A (1992) Community structure and intertidal zonation of the macroinfauna in the Atlantic coast of Uruguay. J coast Res 8:830-839

Defeo O, Layerle C, Masello A (1986) Spatial and temporal structure of the yellow clam Mesodesma mactroides (Deshayes, 1854) in Uruguay. Medio ambiente (Chile) 8: $48-57$

Defeo O, Scarabino V (1990) Ecological singificance of a possible deposit-feeding strategy in Mesodesma mactroides (Deshayes, 1854) (Mollusca: Pelecypoda). Atlántica 12: $55-65$

Defeo O, Seijo JC, Euan J, Liceaga M (1991) Dinámica espacial del esfuerzo pesquero en una pesquería artesanal de la costa atlántica uruguaya. Invest pesq (Chile) 36:17-25
Donn TE (1987) Longshore distribution of Donax serra in two log-spiral bays in the eastern Cape, South Africa. Mar Ecol Prog Ser 35:217-222

Durán LR, Castilla JC (1989) Variation and persistence of the middle rocky intertidal community of central Chile with and without human harvesting. Mar Biol 103:555-562

Estes JA, Palmisano JF (1974) Sea otters: their role in structuring nearshore communities. Science 185:1058-1060

Etchichury MC, Remiro JC (1971) Las arenas de la costa de la República Oriental del Uruguay en el tramo comprendido entre Nueva Palmira y Barra del Chuy. Rev Mus Arg Cienc nat 'Bernardino Rivadavia' Inst nac Inv Cienc nat $7: 153-195$

Gianuca NM (1983) A preliminary account of the ecology of sandy beaches in southern Brazil. In: McLachlan A, Erasmus $T$ (eds) Sandy beaches as ecosystems. W Junk, The Hague, $p$ 413-419

Green RH (1979) Sampling design and statistical methods for environmental biologists. J. Wiley \& Sons, New York

Jaramillo E (1978) Zonación y estructura de la comunidad macrofaunistica en playas de arena del sur de Chile (Mehuín, Valdivia). Stud neotrop Fauna Environ 13:71-92

Jaramillo E, McLachlan A (1993) Community and population responses of the macroinfauna to physical factors over a range of exposed sandy beaches in south-central Chile. Estuar coast Shelf Sci 37:615-624

McLachlan A (1980) Exposed sandy beaches as semi-closed ecosystems. Mar environ Res 4:59-63

McLachlan A (1983) Sandy beach ecology - a review. In: McLachlan A, Erasmus $T$ (eds) Sandy beaches as ecosystems. W Junk, The Hague, p 321-380

McLachlan A (1988) Behavioural adaptations of sandy beach organisms: an ecological perspective. In: Chelazzi G, Vannini $M$ (eds) Behavioral adaptation to intertidal life. Plenum, p 449-475

McLachlan A (1990) Dissipative beaches and macrofauna communities on exposed intertidal sands. J coast Res 6: $57-71$

McLachlan A, Hanekom $N$ (1979) Aspects of the biology, ecology and seasonal fluctuations in biochemical composition of Donax serra in the East Cape. S Afr J Zool 14: 183-193

Méndez SM, Anciaux F (1991) Efectos en las características del agua costera provocados por la descarga del Canal Andreoni en la playa de La Coronilla (Rocha, Uruguay). Fr Mar 8:101-107

Moreno CA, Lunecke KM, Lepez MI (1986) The response of an intertidal Concholepas concholepas population to the pratection from man in southern Chile and the effects on benthic sessile assemblages. Oikos 46:359-364

Moreno CA, Sutherland JP, Jara HF (1984) Man as a predator in the intertidal zone of southern Chile. Oikos 42:155-160

Mouëza $M$, Chessel D (1976) Contribution a l'étude de biologie de Donax trunculus L. (Mollusque: Lamillibranche) dans l'Algerios: analyse statistique de la dispersion de long d'une plage en Baie de Bou Ismail. J exp mar Biol Ecol 21:211-221

Narchi W (1978) Functional anatomy of Donax hanleyanus Philippi 1847 (Donacidae - Bivalvia). Bolm Zool, Univ S Paulo 3:121-142

Navarrete SA, Lubchenco J, Castilla JC (1993) Pacific Ocean coastal ecosystems and global climate change. In: Earth system responses to global change: contrasts between North and South America, Chap 14. Academic Press, $189-193$

Oliva D, Castilla JC (1986) The effect of human exclusion on the population structure of keyhole limpets Fisurella 
Crassa and Fissurella limbata on the coast of central Chile. Mar Ecol 7:201-217

Olivier $\mathrm{S}$, Capezzani D, Carreto J, Christiansen $\mathrm{H}$, Moreno V, de Moreno JA, Penchaszadeh P (1971) Estructura de la comunidad, dinámica de la población y biología de la almeja amarilla (Mesodesma mactroides) en Mar Azul. Proy Des pesq FAO, Serv Inf téc 27:1-90

Paine RT (1984) Ecological determinism in the competition for space. Ecology 65:1339-1348

Penchaszadeh P. Olivier S (1975) Ecología de una población de 'berberecho' (Donax hanleyanus) en Villa Gesell, Argentina. Malacologia 15:133-146

Peterson CH, Andre SV (1980) An experimental analysis of

This article was submitted to the editor interspecific competition among marine filter feeders in a soft-sediment environment. Ecology 61:129-139

Pollovero M (1984) Estudio sobre biocenología y dinámica de la población de 'berberecho', Donax hanleyanus (Philippi 1845) en la zona de playa Arachania, La Paloma, Depto. de Rocha, Uruguay. BS thesis (Lic Oceanogr Biolog), Universidad de la República, Montevideo

Sastre MP (1984) Relationships between environmental factors and Donax denticulatus populations in Puerto Rico. Estuar coast Shelf Sci 19:217-230

Wade BA (1967) Studies on the biology of the West Indian beach clam Donax denticulatus Linne. I. Ecology. Bull mar Sci $17: 149-174$

Manuscript first received: September 6, 1994 Revised version accepted: February 6, 1995 